\title{
Working the day or the night shift? Foraging schedules of Cory's shearwaters vary according to marine habitat
}

\author{
Maria P. Dias ${ }^{1,2, *}$, José P. Granadeiro ${ }^{3}$, Paulo Catry ${ }^{1,2}$ \\ ${ }^{1}$ Eco-Ethology Research Unit, ISPA-IU, 1149-041 Lisbon, Portugal \\ ${ }^{2}$ Museu Nacional de História Natural e da Ciência, Universidade de Lisboa, 1250-102 Lisbon, Portugal \\ ${ }^{3}$ Centro de Estudos do Ambiente e do Mar (CESAM)/Museu Nacional de História Natural e da Ciência, \\ Universidade de Lisboa, 1250-102 Lisbon, Portugal
}

\begin{abstract}
The diel vertical migration of zooplankton and many other organisms is likely to affect the foraging behaviour of marine predators. Among these, shallow divers, such as many seabirds, are particularly constrained by the surface availability of prey items. We analysed the atsea activity of a surface predator of epipelagic and mesopelagic prey, Cory's shearwater Calonectris diomedea, on its several wintering areas (spread throughout the temperate Atlantic Ocean and the Agulhas Current). Individual shearwaters were mainly diurnal when wintering in warmer and shallower waters of the Benguela, Agulhas and Brazilian Currents, and comparatively more nocturnal in colder and deeper waters of the Central South Atlantic and the Northwest Atlantic. Nocturnality also correlated positively with bathymetry and negatively with sea-surface temperature within a single wintering area. This is possibly related to the relative availability of epipelagic and mesopelagic prey in different oceanic sectors, and constitutes the first evidence of such flexibility in the daily routines of a top marine predator across broad spatial scales, with clear expression at population and individual levels.
\end{abstract}

KEY WORDS: Foraging behaviour $\cdot$ Seabirds $\cdot$ Diel vertical migration $\cdot$ Sea-surface temperature Bathymetry Resale or republication not permitted without written consent of the publisher

\section{INTRODUCTION}

Seabirds are ubiquitous and abundant predators in marine ecosystems, where they often play a significant role as consumers of fish, squid and crustaceans (Karpouzi et al. 2007). Birds are mostly visual predators, and foraging by seabirds seems to take place mainly by daylight (McNeil et al. 1993). Nevertheless, exceptions seem to be numerous, and our understanding of the daily routines of seabirds still presents immense gaps. Interesting in their own right, questions about the modes and times or places where seabirds feed may also provide important insights into the ecology of their prey and the functioning of pelagic food webs (Boyd et al. 2006).

Some seabirds are believed to be predominantly nocturnal (e.g. Brooke \& Prince 1991). Nocturnality in feeding occurs more frequently in offshore/ oceanic waters and is comparatively uncommon inshore or over shelf waters (Brooke \& Prince 1991). Nocturnal foragers, such as many storm-petrels (Hydrobatidae) or Pterodroma petrels, have a diet composed by many mesopelagic fishes (particularly Mytcophidae, Photichthyidae and Sternoptychidae) and squids which display diel vertical migrations that make them available to shallow divers during dark- 
ness (Roper \& Young 1975, Gjøsaeter \& Kawaguchi 1980, Harrison et al. 1983, Spear et al. 2007). Mesopelagic fishes and squids are scarce or absent in surface waters of the continental shelf and other shallow areas (Gjøsaeter \& Kawaguchi 1980, Nybakken 2001, Pusch et al. 2004) and specialist predators of mesopelagic prey (such as several species of Oceanodroma, Fregetta, Pterodroma and Bulweria; Spear et al. 2007) avoid foraging in inshore waters (e.g. Warham 1990). Diel vertical migrations (DVM) of plankton and their predators do not happen only in deep sea areas (Hays 2003), but the fact that inshore foragers are known to feed mostly by day suggests that any increased availability at the surface is not large enough to counteract the disadvantages of feeding in the darkness for surface or shallow-diving visual predators. If the above reasoning is correct, we would predict that for species able to exploit both inshore and offshore environments, and able to feed by day and by night, the daily routines could differ markedly between coastal waters and the deep sea.

Recent developments in technology allow the study of pelagic seabird predators when freed from spatial and temporal constraints linked to reproduction (Mackley et al. 2010). The deployment of activity and positional recorders in such wide-ranging birds allows the mapping of behavioural patterns over large spatial scales, for the first time portraying 'behavioural seascapes' that may reveal interesting patterns, and thus help to further our knowledge of pelagic systems.

Here, using an exceptional dataset with almost 80 bird tracks, we study the at-sea behaviour of Cory's shearwaters Calonectris diomedea in their widely scattered wintering areas, ranging from the oceanic waters of the North and South Atlantic to the shelf areas off South African and South American coasts (Catry et al. 2011, Dias et al. 2011). These areas differ markedly in their oceanographic conditions, namely with respect to bathymetry (varying from the shallow waters of the Benguela and Agulhas Currents to the deep waters of the Northwest [NW] and Central South [CS] Atlantic) and to sea-surface temperature (with the oceanic and upwelling areas of the Benguela Current considerably colder than those of Brazilian and Agulhas Currents; data from www. ngdc.noaa.gov/ and http://poet.jpl.nasa.gov/). We compared the nocturnality versus diurnality of Cory's shearwaters at these different wintering locations, and examined the links between their behavioural patterns and oceanographic features. This mediumsized seabird is a shallow diver (almost never diving beyond $10 \mathrm{~m}_{\text {; }}$ Paiva et al. 2010), so its feeding ecology is expected to be highly constrained by the surface availability of the fish and squid upon which it is known to prey (Granadeiro et al. 1998, Petry et al. 2009, Bugoni et al. 2010).

\section{MATERIALS AND METHODS}

\section{Bird tracking and activity data}

We collected data on the wintering locations (December to February) and at-sea activity of 73 Cory's shearwaters Calonectris diomedea from the Selvagem Grande colony $\left(30^{\circ} 09^{\prime} \mathrm{N}, 15^{\circ} 52^{\prime} \mathrm{W}\right.$; Madeira Archipelago, Portugal) tracked over $4 \mathrm{yr}$ (2006 to 2010) using leg-mounted geolocators (mk 7 models; 3.6 g; British Antarctic Survey). The devices were deployed in breeding birds at the end of each season (August-September) and recovered in the beginning of the following breeding season (AprilJune). Geolocators record maximum light levels at 10 min intervals, from which we estimated sunset and sunrise times and calculated the positions of each bird twice a day, with an approximate accuracy of $186 \pm 114 \mathrm{~km}$ (Phillips et al. 2004). Light data were analysed using 'TransEdit', to check for integrity of light curves and to fit dawn and dusk times, and 'Birdtrack' software, to estimate the latitude from day length and the longitude from the time of local midday relative to Greenwich Mean Time. We assumed a sun elevation angle of $-4.5^{\circ}$, based on known positions obtained during ground-truthing of the loggers, carried out before and after deployment. Unrealistic positions (those resulting from interference of light curves at dawn or dusk, or around equinox periods) were removed from the analyses.

Geolocators also registered saltwater immersion data (wet/dry) at $3 \mathrm{~s}$ intervals and sea-surface temperature (SST) if continuously immersed for $20 \mathrm{~min}$. Immersion data were used to estimate the percentage of time spent on the sea surface and the number of landings per hour (a good predictor of foraging effort; Shaffer et al. 2001), separately for diurnal and nocturnal periods (based on local sunset and sunrise times). We then calculated (1) a 'night flight index' (NFI) as the difference between the proportions of time spent in flight during darkness and during daylight, divided by the highest of these 2 values, and (2) a 'night landing index' (NLI) as the difference between the nocturnal and the diurnal landing rates (landings per hour), divided by the highest of these 2 values. Both indexes vary between -1 (flight or landing activity restricted to daylight) and 1 (flight or landing restricted 
to night), and division by the highest value ensures linear behaviour of the index in relation to the variation in values of diurnal or nocturnal activity.

The indexes were calculated for each bird and each day during the wintering period (i.e. after arrival at the wintering area, which occurs on average during mid-December until the start of the return migration in mid-February). Cory's shearwaters rarely changed their staging area during the course of the wintering period; for the only 2 occasions when this happened, we considered only the data from the location where the bird spent most of its wintering time. In order to avoid the potential effect of the progress of the winter in activity patterns (e.g. due to the forthcoming return migration), we excluded all data collected after 31th January and only considered in the analysis birds for which we had gathered data for at least $20 \mathrm{~d}$. This resulted in a final dataset of 19 birds in the 2006/2007 migration (4: Agulhas Current, 7: CS Atlantic, 7: Benguela Current, 1: Brazilian Current), 14 in 2007/2008 (2: Agulhas Current, 9: Benguela Current, 1: NW Atlantic, 2: Brazilian Current), 21 in 2008/2009 (2: Agulhas Current, 1: CS Atlantic, 15: Benguela, 2: NW Atlantic, 1: Brazilian Current) and 19 in 2009/2010 (3: Agulhas Current, 15: Benguela Current, 1: NW Atlantic). The mean wintering period considered for each area was $49 \mathrm{~d}$ for birds in the Agulhas Current, $48 \mathrm{~d}$ in the CS Atlantic, $48 \mathrm{~d}$ in the Benguela Current, $59 \mathrm{~d}$ in the NW Atlantic and $54 \mathrm{~d}$ in Brazilian Current.

\section{Data analysis}

Since there were no major deviations from normality in the activity patterns, we compared wintering areas using ANOVAs, after averaging the activity data per individual, and including the year in the models, as a fixed factor.

We analysed the influence of oceanographic features (SST and bathymetry), lunar cycle and day length on the activity of Cory's shearwaters that wintered in the Benguela Current (for which we obtained a sample of birds [ $n=46$ ] that allowed interindividual comparisons and a considerable variability in SST and bathymetry values).

For each bird $\times$ day term we calculated (1) the average value of SST provided by the geolocator, (2) the closest value of bathymetry (in metres; on-land positions were also included in order to avoid a bias toward deeper values due to the low accuracy of the geolocation method; we considered the average position of each bird on each day; the bathymetry values were obtained from www.ngdc.noaa.gov/mgg/global/ global.html, with a resolution of 1 arc-minute), (3) the fraction of the moon illuminated at midnight (expressed as a proportion, obtained from the United States Naval Meteorology and Oceanography Command (www.usno.navy.mil/USNO/astronomicalapplications/data-services/frac-moon-ill) and (4) the day length (in hours, based on local sunset and sunrise times). The quality of the SST values provided by the geolocators was evaluated by comparison with local temperature data obtained by remote sensing (significant correlation between the values obtained by the geolocators and registered by remote sensing: $\mathrm{r}=0.87, \mathrm{df}=68, \mathrm{p}<0.001 ;$ values available at http://poet.jpl.nasa.gov/).

The relationship between each variable and the activity indexes was analysed using linear mixed models, in which Year was also included as a fixed factor and the Bird Identity as a random factor. The models were initially fitted with all predictors and then compared with increasingly simpler nested models, obtained by removing non-significant terms (until only significant terms $[p<0.05]$ remained in the model). Comparisons between models were based on log-likelihood ratio tests (Zuur et al. 2009); all the analyses were performed with the package lme4 (Bates et al. 2011), under the R environment ( $R$ Development Core Team 2010).

To map the activity patterns of Cory's shearwaters during the wintering period, we created a $2^{\circ}$ (latitude and longitude) grid and assigned the position of each bird $\times$ day term to the corresponding pixel. The average value of indexes was then calculated for each pixel based on all bird $\times$ day values obtained within its limits.

In order to analyse the diel variation of the landing rate, we calculated the average number of landings per hour for each individual and then considered the average values $( \pm \mathrm{SE})$ of the several individuals in each wintering area.

We tracked 4 ind. for $>1$ non-breeding season. Nevertheless, and except otherwise stated, only 1 track per individual (randomly chosen) was used in the analyses.

\section{RESULTS}

\section{Comparison between wintering areas}

The activity patterns of Cory's shearwaters Calonectris diomedea were noticeably different among wintering areas (Fig. 1). Birds in the shelf areas off 

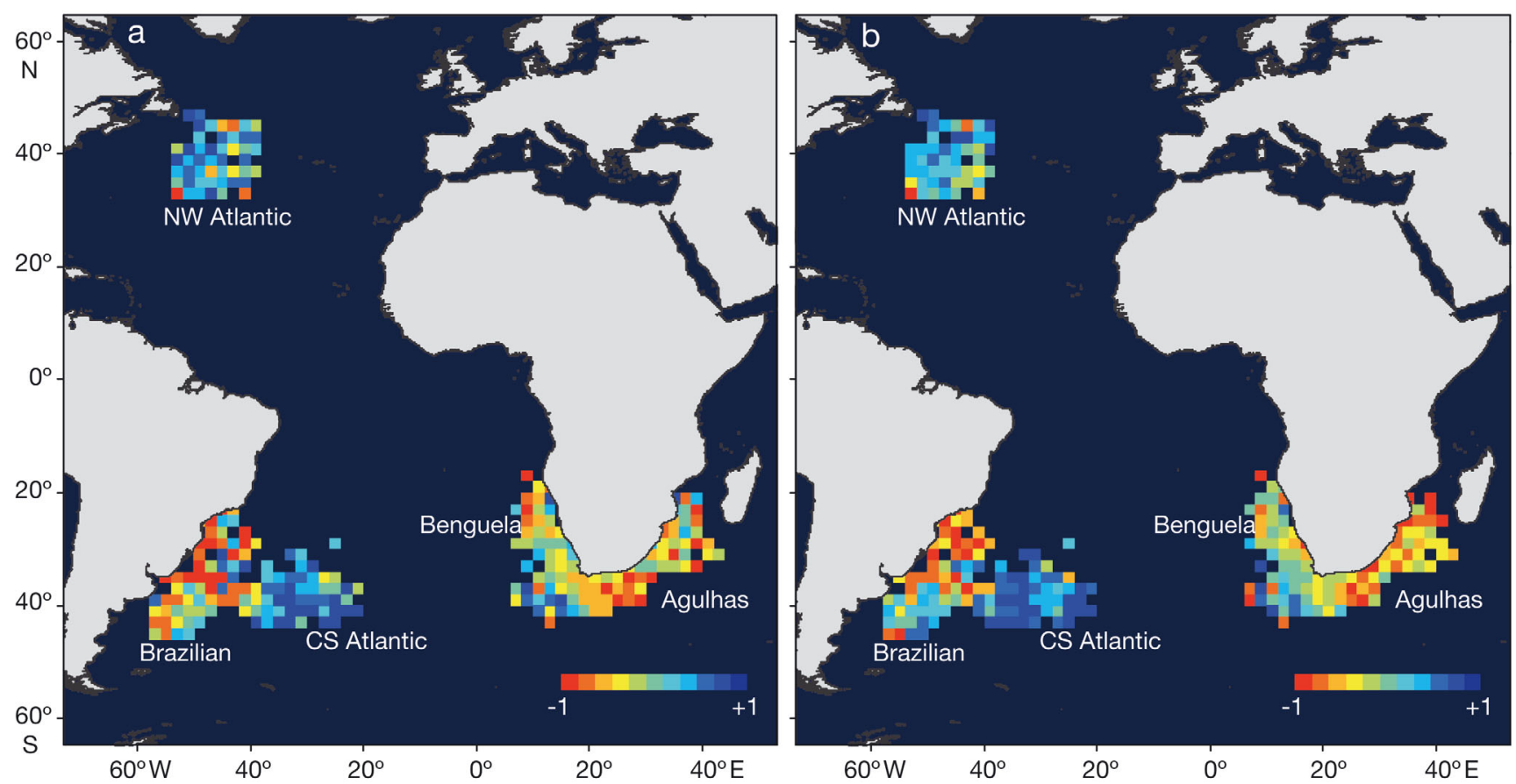

Fig. 1. Calonectris diomedea. 'Behavioural seascape' depicting spatial variation in the allocation of activity to day and nighttime by Cory's shearwaters during the non-breeding season. Colours reflect differences in the (a) night flight index and (b) night landing index. Colour scale: red = predominantly diurnal behaviour, blue = predominantly nocturnal behaviour. The maps are based on combined data from 73 ind. (4: Northwest Atlantic, 4: Brazilian Current, 8: Central South Atlantic, 46: Benguela Current, 11: Agulhas Current)

South African and South American coasts (Benguela, Agulhas and Brazilian Currents) presented predominantly diurnal activity, whereas those that stayed in the oceanic waters of the NW Atlantic and CS Atlantic showed comparatively greater nocturnal activity (significant effect of wintering area on NFI and on NLI; Table 1 and Fig. 2).

This broad pattern was patent even when analysing the intra-individual variation in foraging behaviour across years: 3 birds that changed from the

Table 1. Calonectris diomedea. Comparison of night activity indexes of Cory's shearwaters among wintering areas (results from ANOVA tests, in which Year was included as a factor)

\begin{tabular}{|lccc|}
\hline & df & $F$ & $p$ \\
\hline Night flight index & & & \\
Wintering area & 4 & 16.73 & $<0.001$ \\
Year & 3 & 1.52 & 0.22 \\
Wintering area $\times$ Year & 8 & 0.89 & 0.53 \\
Residuals & 57 & & \\
Night landing index & & & \\
Wintering area & 4 & 28.55 & $<0.001$ \\
Year & 3 & 4.28 & 0.009 \\
Wintering area $\times$ Year & 8 & 2.10 & 0.05 \\
Residuals & 57 & & \\
\hline
\end{tabular}

CS Atlantic to the Benguela or Brazilian Currents in successive winters also shifted from more nocturnal to more diurnal behaviour (average NFIs for the 3 ind.: CS Atlantic $=-0.29$; Benguela/Brazilian Currents $=-0.81$, NLIs: CS Atlantic $=0.29$; Benguela/ Brazilian Currents $=-0.59$; all within-individual comparisons between wintering areas were significant; $t$-tests: all $t>5.11$, all $\mathrm{p}<0.001$ ). An opposite shift in behavioural patterns was detected in another bird that changed from the Brazilian Current to the Northwest Atlantic (NFI: Brazilian Current $=-0.61$; NW Atlantic $=-0.45 ; t$-test: $t=2.00, \mathrm{df}=65, \mathrm{p}=0.05$ ).

Cory's shearwaters that wintered in the CS Atlantic or in the NW Atlantic were particularly active (in their landing activity) just before sunrise and soon after (or during) sunset, a pattern that contrasts observations recorded in other wintering areas (Fig. 3).

\section{Relationship between environmental variables and activity patterns}

Across wintering areas, shearwaters appeared to have a more nocturnal behaviour pattern in colder and deeper waters (Fig. 2). Even when considering 

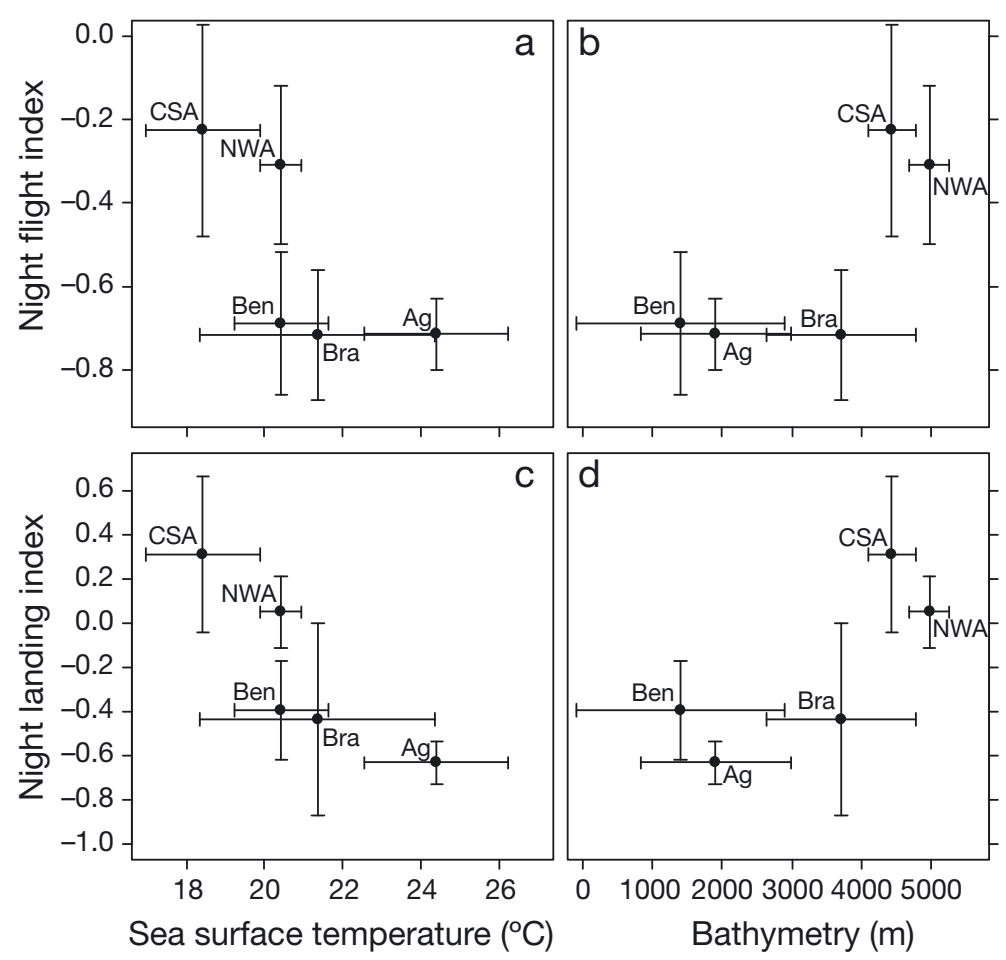

Fig. 2. Calonectris diomedea. Relationship between nocturnal activity of Cory's shearwaters as measured by $(a, b)$ the night flight index and $(\mathrm{c}, \mathrm{d})$ the night landing index, and $(\mathrm{a}, \mathrm{c})$ sea-surface temperature and (b,d) bathymetry. All means \pm SD. CSA: Central South Atlantic ( $n=8$ ind.); NWA: Northwest Atlantic $(\mathrm{n}=4)$; Ben: Benguela Current $(\mathrm{n}=$ 46); Bra: Brazilian Current $(\mathrm{n}=4)$; Ag: Agulhas Current $(\mathrm{n}=11)$. The differences in activity indexes among wintering areas are highly significant (Table 1) a single geographical area for which we have a larger data set (the Benguela Current), individuals that used deeper and colder waters were more nocturnal than those using shallower and warmer areas (Table 2). The moon also affected the behaviour of birds, by increasing the proportion of time spent in flight during the night, but also by decreasing the nocturnal landing rate. Day length negatively affected the proportion of time spent in flight during the night, but not the nocturnal landing rate (Table 2).

\section{DISCUSSION}

The present study is the first to map broad 'behavioural seascapes' to reveal the flexibility of the organization of daily activity budgets of a pelagic predator. As predicted, Cory's shearwaters Calonectris diomedea show different degrees of nocturnal activity, depending on the marine region and habitat in which they are foraging. To our knowledge, this type of flexibility has never been shown in a single species across such a large spatial scale and with such clear expression at population and at individual levels.

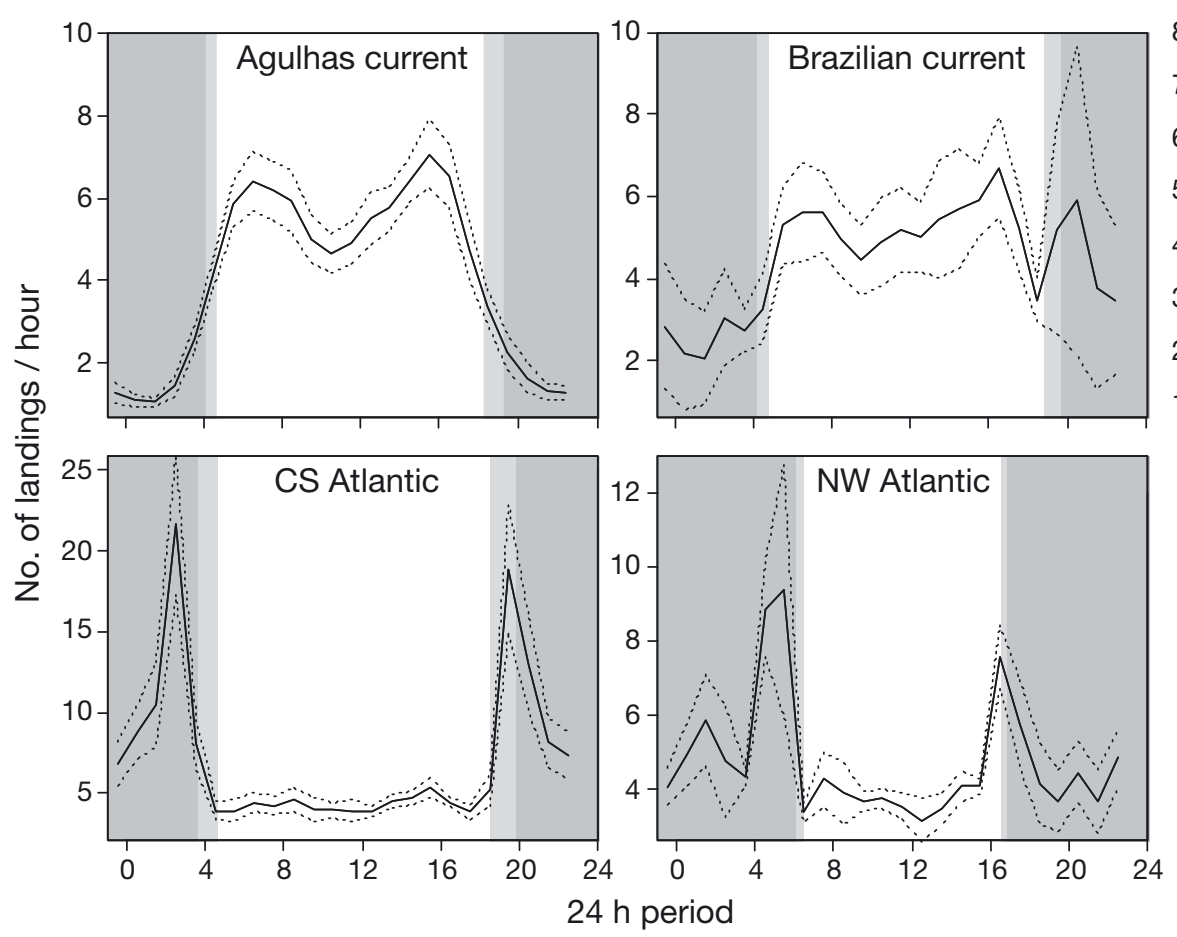

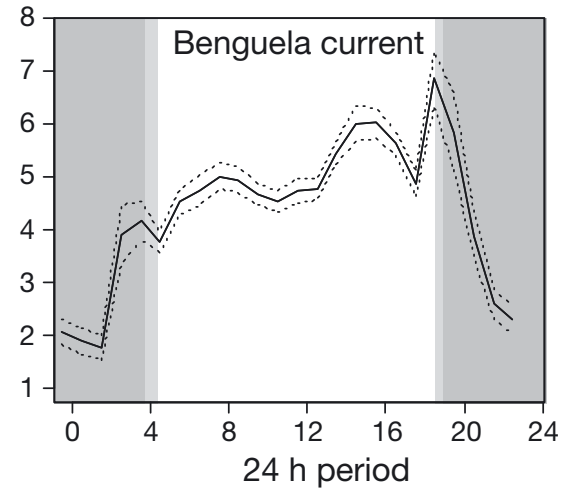

Fig. 3. Calonectris diomedea. Number of landings per hour (solid lines: means; broken lines: SE) of Cory's shearwater throughout the $24 \mathrm{~h}$ period (local time) in different wintering areas. Dark grey area: night; light grey area: crepuscular phase 
Table 2. Calonectris diomedea. Linear mixed models relating night activity indexes to oceanographic variables (seasurface temperature and bathymetry), moon and day length. Only Cory's shearwaters wintering in the Benguela Current $(\mathrm{n}=46)$ were included in analyses

\begin{tabular}{|c|c|c|c|}
\hline & Model estimate \pm SE & $t$ & $\mathrm{p}$ \\
\hline \multicolumn{4}{|c|}{ Night flight index } \\
\hline Bathymetry & $1.49 \times 10^{-6} \pm 5.1 \times 10^{-7}$ & 2.931 & 0.003 \\
\hline Moon & $0.06 \pm 0.02$ & 3.073 & 0.002 \\
\hline Day length & $-0.09 \pm 0.02$ & -4.125 & 0.000 \\
\hline \multicolumn{4}{|c|}{ Night landing index } \\
\hline $\begin{array}{l}\text { Sea-surface } \\
\text { temperature }\end{array}$ & $-0.04 \pm 0.01$ & -5.657 & 0.000 \\
\hline Bathymetry & $1.57 \times 10^{-6} \pm 7.7 \times 10^{-7}$ & 2.024 & 0.043 \\
\hline Moon & $-0.09 \pm 0.03$ & -2.86 & 0.004 \\
\hline
\end{tabular}

Cory's shearwaters were comparatively more nocturnal when wintering in open ocean areas (NW Atlantic and CS Atlantic) than in the shelf or upwelling areas located off the coasts of South Africa and South America (Benguela, Agulhas and Brazilian Currents). Remarkably, individuals that shifted between areas in successive winters also changed their foraging schedules accordingly. The diet of Cory's shearwaters during the non-breeding period is almost unknown (except for the Brazilian Current, where the species seems to prey on epipelagic prey similar to those found in breeding grounds; Petry et al. 2009, Bugoni et al. 2010). Therefore, we cannot directly link the changes in foraging behaviour with the specific diet in each area. Nevertheless, we can hypothesize that these dissimilarities in activity schedules are most probably related to marked differences in the diel patterns of surface prey availability among areas, with birds wintering in open oceanic waters probably feeding mainly on DVM prey that are only accessible during the night. There are some lines of evidence to support this hypothesis. First, the mesopelagic prey species that form the major component of pelagic food webs, due to their superabundance (Kozlov 1995, Nybakken 2001, Catul et al. 2011), are available to surface predators during the night, due to their DVM (reviewed by Hays 2003). Most of these species have bioluminescent organs (Herring 1987), which possibly facilitate prey detection and capture in the dark. The DVM of these and other abundant marine organisms is known to shape the behavioural routines of several other top pelagic predators such as sharks, seals and seabirds (Croxall et al. 1985, Wilson et al. 1993, Regular et al. 2010, Saunders et al. 2010). However, while most of these predators (such as penguins, guillemots and seals), as deep-divers, can respond by adjusting their diving depth and daily routines in accordance with DVM and diel variation in light levels (Wilson et al. 1993, Biuw et al. 2010, Regular et al. 2010), shallow divers, such as Cory's shearwaters, are highly constrained to the prey availability in surface layers. In these cases, the foraging schedules will most probably be dictated by the relative availability of prey throughout the diel cycle.

Another type of supporting evidence is the occurrence of 2 marked peaks in the foraging activity of Cory's shearwaters, around dawn and dusk, but these are only obvious in the offshore or oceanic wintering areas. Such activity peaks are frequently observed in visual marine predators that feed on DVM prey (Croxall et al. 1985, Falk et al. 2002, Regular et al. 2010, Scheffer et al. 2010), and can be explained by the improved surface availability of the prey when light levels are high enough to enable visual foraging (Piersma et al. 1988, Regular et al. 2010, Scheffer et al. 2010).

We found a significant relationship between the oceanographic environment and the foraging behaviour of Cory's shearwaters - they were mainly nocturnal when wintering in colder and deeper wintering areas, and more diurnal when on the warmer and shallower waters of Benguela, Agulhas and Brazilian Currents. Even at a finer scale, within a single wintering area (Benguela Current), Cory's shearwaters presented some flexibility in their nocturnality, which was also closely related with both local bathymetry and SST. This may also be related with differences in the surface availability of prey throughout the day on areas with distinct oceanographic conditions. The abundance of mesopelagic fish, for instance, is closely related to bathymetry (Gjøsaeter \& Kawaguchi 1980, Nybakken 2001, Pusch et al. 2004), so a reduced availability of vertically migrating organisms is expected in shallow waters. In fact, and despite the lack of studies relating the magnitude of the DVM phenomena to oceanographic features, some indirect evidence of this correlation arises from studying the behaviour of several marine predators. Elephant seals Mirounga leonina, for example, present a clear diel dive pattern when foraging in deep open pelagic waters, while this diel pattern is absent when foraging in shelf regions (Biuw et al. 2007, 2010). Similarly, Brünnich's guillemots Uria lomvia, king penguins Aptenodytes patagonicus and great shearwaters Puffinus gravis increase their foraging activity both at sunrise and sunset in response to the DVM of their prey, but again only when foraging in deeper (in the case of guillemots) or colder areas (Falk et al. 2002, Ronconi et al. 2010, Scheffer et al. 2010). 
Day length is known to influence the flight activity of seabirds at broader scales (Pinet et al. 2011), and the relatively shortened day lengths experienced by the birds that wintered in the NW Atlantic can partially explain their increased nocturnality in this area. Nevertheless, birds that wintered in different sectors of the South Atlantic met broadly similar conditions of daylight duration and yet markedly differed in their behaviour, so we conclude that the variable degree of nocturnality reported here is not primarily linked to differences in the relative durations of day and night.

Finally, we also found a strong influence of the lunar cycle on the behavioural patterns of Cory's shearwaters. Their nocturnal flight activity increases on moonlit nights (in line with what was already observed for several other seabird species; Phalan et al. 2007, Yamamoto et al. 2008, Mackley et al. 2011, Pinet et al. 2011), but their nocturnal landing activity decreases. Since the indicators of nocturnal activity vary in opposite directions, we hypothesize that the increase in flight activity represents a higher searching effort, but a lower efficiency around full-moon (Phalan et al. 2007, Mackley et al. 2011). This could be explained by the reduced feeding opportunities during moonlit nights, given that DVM prey tend to occur deeper in the water column during full moons (Horning \& Trillmich 1999, Hernández-Leon et al. 2001, Benoit-Bird et al. 2009, Regular et al. 2011).

\section{CONCLUSIONS}

The present study shows that Cory's shearwaters Calonectris diomedea present a remarkable flexibility in their daily routines, which correlates with the oceanographic features of the broad geographical areas in which they winter. Although we have not yet been able to link the observed patterns to the specific diet and prey availability at each site (which are mostly unknown), comparison with the patterns observed for other well-studied taxa strongly suggests that Cory's shearwaters mainly feed on DVM prey in open-ocean areas, and possibly on more epipelagic prey in shelf areas.

Previous research has also documented a notable flexibility in other behavioural traits of Cory's shearwaters, such as in their migratory routes and destinations, both within and among individuals and colonies (Catry et al. 2011, Dias et al. 2011). Such plasticity in several such aspects of the life cycle of a long-lived species may represent an advantage in the context of human-induced changes in marine ecosystems (Grémillet \& Boulinier 2009).
Acknowledgements. This research was funded by Fundação para a Ciência e a Tecnologia (FCT - Portugal) and FEDER, through PTDC/MAR/71927/2006 and PEst-OE/MAR/UI0331/ 2011 projects. M. Dias benefited from a postdoctoral fellowship (FCT-BPD/46827/08). Parque Natural da Madeira (P. Oliveira, D. Menezes and C. Santos) provided permission and logistic support for work on Selvagens. R. A. Phillips (British Antarctic Survey) provided invaluable support in geolocation data analysis. H. Alonso and many others helped with fieldwork.

\section{LITERATURE CITED}

Bates D, Maechler M, Bolker B (2011) lme4: linear mixedeffects models using S4 classes. R package Version 0.999375-39

Benoit-Bird KJ, Au WWL, Wisdom DW (2009) Nocturnal light and lunar cycle effects on diel migration of micronekton. Limnol Oceanogr 54:1789-1800

Biuw M, Boehme L, Guinet C, Hindell M and others (2007) Variations in behavior and condition of a Southern Ocean top predator in relation to in situ oceanographic conditions. Proc Natl Acad Sci USA 104:13705-13710

> Biuw M, Nøst OA, Stien A, Zhou Q, Lydersen C, Kovacs KM (2010) Effects of hydrographic variability on the spatial, seasonal and diel diving patterns of southern elephant seals in the eastern Weddell Sea. PLoS ONE 5:e13816

Boyd I, Wanless S, Camphuysen CJ (2006) Top predators in marine ecosystems: their role in monitoring and management. Cambridge University Press, Cambridge

Brooke ML, Prince PA (1991) Nocturnality in seabirds. Proc Int Ornithol Congr 20:1113-1121

> Bugoni L, McGill RAR, Furness RW (2010) The importance of pelagic longline fishery discards for a seabird community determined through stable isotope analysis. J Exp Mar Biol Ecol 391:190-200

> Catry P, Dias MP, Phillips RA, Granadeiro JP (2011) Different means to the same end: long-distance migrant seabirds from two colonies differ in behaviour, despite common wintering grounds. PLoS ONE 6:e26079

> Catul V, Gauns M, Karuppasamy PK (2011) A review on mesopelagic fishes belonging to family Myctophidae. Rev Fish Biol Fish 21:339-354

> Croxall JP, Everson I, Kooyman GL, Ricketts C, Davis RW (1985) Fur seal diving behaviour in relation to vertical distribution of krill. J Anim Ecol 54:1-8

> Dias MP, Granadeiro JP, Phillips RA, Alonso H, Catry P (2011) Breaking the routine: individual Cory's shearwaters shift winter destinations between hemispheres and across ocean basins. Proc Biol Sci 278:1786-1793

Falk K, Benvenuti S, Dall'Antonia L, Gilchrist G, Kampp K (2002) Foraging behaviour of thick-billed murres breeding in different sectors of the North Water polynya: an inter-colony comparison. Mar Ecol Prog Ser 231:293-302

Gjøsaeter J, Kawaguchi K (1980) A review of the world resources of mesopelagic fish. FAO Fish Tech Pap 193:1-51

Granadeiro JP, Monteiro LR, Furness RW (1998) Diet and feeding ecology of Cory's shearwater Calonectris diomedea in the Azores, north-east Atlantic. Mar Ecol Prog Ser 166:267-276

Grémillet D, Boulinier T (2009) Spatial ecology and conservation of seabirds facing global climate change: a review. Mar Ecol Prog Ser 391:121-137

Harrison CS, Hida TS, Seki MP (1983) Hawaiian seabird 
feeding ecology. Wildl Monogr 85:1-71

Hays G (2003) A review of the adaptive significance and ecosystem consequences of zooplankton diel vertical migrations. Hydrobiologia 503:163-170

- Hernández-Leon S, Almeida C, Yebra L, Arístegui J, Fernández de Puelles ML, García-Braun J (2001) Zooplankton abundance in subtropical waters: Is there a lunar cycle? Sci Mar 65:59-63

Herring PJ (1987) Systematic distribution of bioluminescence in living organisms. J Biolumin Chemilumin 1: $147-163$

Horning M, Trillmich F (1999) Lunar cycles in diel prey migrations exert a stronger effect on the diving of juveniles than adult Galápagos fur seals. Proc Biol Sci 266: 1127-1132

Karpouzi VS, Watson R, Pauly D (2007) Modelling and mapping resource overlap between seabirds and fisheries on a global scale: a preliminary assessment. Mar Ecol Prog Ser 343:87-99

Kozlov AN (1995) A review of the trophic role of mesopelagic fish of the family Myctophidae in the Southern Ocean ecosystem. CCAMLR Sci 2:71-77

> Mackley E, Phillips RA, Silk JRD, Wakefield ED, Afanasyev V, Fox JW, Furness RW (2010) Free as a bird? Activity patterns of albatrosses during the nonbreeding period. Mar Ecol Prog Ser 406:291-303

Mackley EK, Phillips RA, Silk JRD, Wakefield ED, Afanasyev V, Furness RW (2011) At-sea activity patterns of breeding and nonbreeding white-chinned petrels Procellaria aequinoctialis from South Georgia. Mar Biol 158: 429-438

McNeil R, Drapeau P, Pierotti R (1993) Nocturnality in colonial waterbirds: occurrence, special adaptations, and suspected benefits. Curr Ornithol 10:187-246

Nybakken JW (2001) Marine biology. An ecological approach, 5th edn. Benjamin Cummings, San Francisco, CA

> Paiva VH, Geraldes P, Ramírez I, Meirinho A, Garthe S, Ramos JA (2010) Foraging plasticity in a pelagic seabird species along a marine productivity gradient. Mar Ecol Prog Ser 398:259-274

Petry MV, Kruger L, Fonseca VDS, Brummelhaus J, Piuco RC (2009) Diet and ingestion of synthetics by Cory's shearwater Calonectris diomedea off southern Brazil. J Ornithol 150:601-606

Phalan B, Phillips RA, Silk JRD, Afanasyev V and others (2007) Foraging behaviour of four albatross species by night and day. Mar Ecol Prog Ser 340:271-286

Phillips RA, Silk JRD, Croxall JP, Afanasyev V, Briggs DR (2004) Accuracy of geolocation estimates for flying seabirds. Mar Ecol Prog Ser 266: 265-272

Piersma T, Lindeboom R, van Eerden MR (1988) Foraging rhythm of great crested grebes Podiceps cristatus adjusted to diel variations in the vertical distribution of

Editorial responsibility: Christine Paetzold, Oldendorf/Luhe, Germany their prey Osmerus eperlanus in a shallow eutrophic lake in The Netherlands. Oecologia 76:481-486

Pinet P, Jaeger A, Cordier E, Potin G, Le Corre M (2011) Celestial moderation of tropical seabird behavior. PLoS ONE 6:e27663

Pusch C, Beckmann A, Porteiro FM, Westernhagen H (2004) The influence of seamounts on mesopelagic fish communities. Arch Fish Mar Res 51:165-186

R Development Core Team (2010) R: a language and environment for statistical computing. R Foundation for Statistical Computing, Vienna

Regular PM, Davoren GK, Hedd A, Montevecchi WA (2010) Crepuscular foraging by a pursuit-diving seabird: tactics of common murres in response to the diel vertical migration of capelin. Mar Ecol Prog Ser 415:295-304

Regular PM, Hedd A, Montevecchi WA (2011) Fishing in the dark: a pursuit-diving seabird modifies foraging behaviour in response to nocturnal light levels. PLoS ONE 6: e26763

Ronconi RA, Ryan PG, Ropert-Coudert Y (2010) Diving of great shearwaters (Puffinus gravis) in cold and warm water regions of the South Atlantic Ocean. PLoS ONE 5: e15508

Roper CFE, Young RE (1975) Vertical distribution of pelagic cephalopods. Smithson Contrib Zool 209:1-51

Saunders RA, Royer F, Clarke MW (2010) Winter migration and diving behaviour of porbeagle shark, Lamna nasus, in the Northeast Atlantic. ICES J Mar Sci 67: 166-174

Scheffer A, Trathan PN, Collins M (2010) Foraging behaviour of king penguins (Aptenodytes patagonicus) in relation to predictable mesoscale oceanographic features in the Polar Front Zone to the north of South Georgia. Prog Oceanogr 86:232-245

Shaffer SA, Costa DP, Weimerskirch H (2001) Behavioural factors affecting foraging effort of breeding wandering albatrosses. J Anim Ecol 70:864-874

Spear LB, Ainley DG, Walker WA (2007) Foraging dynamics of seabirds in the eastern tropical pacific ocean. Stud Avian Biol 35:1-99

Warham J (1990) The petrels. Their ecology and breeding systems. Academic Press, San Diego, CA

Wilson RP, Puetz K, Bost CA, Culik BM, Bannasch R, Reins $\mathrm{T}$, Adelung D (1993) Diel dive depth in penguins in relation to diel vertical migration of prey: Whose dinner by candlelight? Mar Ecol Prog Ser 94:101-104

Yamamoto T, Takahashi A, Yoda K, Katsumata N, Watanabe S, Sato K, Trathan PN (2008) The lunar cycle affects at-sea behaviour in a pelagic seabird, the streaked shearwater, Calonectris leucomelas. Anim Behav 76: 1647-1652

Zuur AF, Ieno EN, Walker NJ, Saveliev AA, Smith GM (2009) Mixed effects models and extensions in ecology with R. Springer, New York, NY

Submitted: November 21, 2011; Accepted: July 30, 2012 Proofs received from author(s): October 18, 2012 